Barbara PISARSKA

Szkoła Główna Turystyki i Rekreacji w Warszawie

\title{
BADANIE BUDŻETU CZASU STUDENTÓW, W TYM ICH CZASU WOLNEGO - STUDIA PRZYPADKÓW
}

\section{Wprowadzenie}

Celem niniejszego opracowania jest: przybliżenie podstaw teoretycznych $\mathrm{z}$ literatury przedmiotu; przedstawienie metody badania budżetu czasu studentów, w tym ich czasu wolnego; przytoczenie budżetów czasu wybranych przypadków i ich analiza; sformułowanie postulatów doskonalenia niniejszego podejścia badawczego.

Budżet czasu to zestawienie odcinków czasu przewidzianych na realizację różnych czynności życiowych (PIĘTA 2008, s. 17). Jego badanie polega na mierzeniu, liczeniu (minut, godzin) i porównywaniu zagospodarowania określonego przedziału czasu (dnia, tygodnia, miesiąca, roku) przez określone grupy społeczne (wiekowe: uczniowie, studenci, emeryci; zawodowe: nauczyciele, ekspedienci, górnicy; mieszkańcy konkretnego obszaru: miejscowości, powiatu, województwa, kraju).

Wśród metod badań budżetu czasu wyróżniamy metody terenowe i kameralne.

Podstawowe sposoby uzyskiwania materiału do badań, to:

1) kwestionariusz wywiadu z pytaniami zamkniętymi lub otwartymi;

2) skategoryzowana ankieta;

3) książeczka zajęć (podmiot badania rejestruje czynności według formularza albo swobodnie); 
4) obserwacja, czyli „fotografia” toku dnia, tygodnia badanych osób). Materiały z wywiadów, ankiet, książeczek zajęć czy obserwacji opracowywane są za pomocą metod statystycznych, a następnie wyjaśniane opisowo.

Istnieje wiele trudności w porównywaniu wyników badań. Według E. WNUKA-LIPIŃSKIEGO (1972, s. 58-65, 71-75) - ich przyczyny tkwią w:

1) rozumieniu podstawowych kategorii budżetu czasu, a głównie czasu wolnego (nieraz istnieje płynna granica między czasem pracy a czasem wolnym i czasem obowiązków domowych);

2) złożoności problematyki gospodarki czasem (zależy ona nie tylko od obiektywnych warunków społeczno-ekonomicznych, ale również od typów dni tygodnia: dzień roboczy, przedświąteczny, świąteczny, oraz sezonów roku);

3) odmienności podejść metodologicznych;

4) różnych technikach badawczych: ankieta, wywiad z kwestionariuszem, książeczka rejestracji zajęć, „fotografia” rozkładu zajęć (obserwacja);

5) dużym zróżnicowaniu podmiotów badań, tzn. obejmowaniu badaniami wąskich grup środowiskowych, głównie zawodowych, np. pracowników PKP, robotników „Azotów” w Puławach, ekspedientek, urzędniczek $w$ danym mieście.

Z powyższych powodów większość badań - zdaniem wspomnianego autora - pełniła jedynie funkcje poznawcze, a nie mogła być empiryczną podstawą metodologicznie poprawnych uogólnien. $Z$ perspektywy lat należy stwierdzić, że proces dostrzeganej wówczas dezintegracji metodologicznej uległ niestety znacznemu pogłębieniu $\mathrm{w}$ związku $\mathrm{z}$ uszczupleniem środków przeznaczonych na badania społeczne o szerszym zasięgu (ogólnokrajowym, regionalnym, ogólnomiejskim). Z prac S. TOCZEK-WERNER, M. SOŁTYSIK (1997, s. 14-18, 2006, s. 421-428) wiadomo, że w latach 19801996 wydano 71 ważniejszych opracowań poświęconych czasowi wolnemu mieszkańców większych miast Polski. Na ich podstawie można stwierdzić wyraźne zmiany $\mathrm{w}$ tej problematyce. Wynikały one $\mathrm{z}$ przemian polityczno-gospodarczych, jakie zaszły w tym okresie w naszym kraju.

W budżecie czasu większości ludzi występują cztery podstawowe typy zajęć - związane z fizjologią, nauką i pracą, z obowiązkami domowymi oraz z czasem wolnym. Istnieje wiele klasyfikacji uszczegółowiających wymieniony podział; warto przytoczyć ten, który stosowany był w badaniach budżetu czasu przez GUS (SŁABY 2000, s. 9): 
1) czynności fizjologiczne, czyli: sen, higiena, spożywanie posiłków;

2) prace zarobkowe - główna i dodatkowa;

3) nauka - zorganizowana i samokształcenie;

4) zajęcia i prace domowe: przygotowywanie posiłków, sprzątanie, pranie, prasowanie;

5) działalność w organizacjach świeckich i religijnych;

6) życie towarzyskie i rozrywka;

7) udział w sporcie i rekreacji;

8) zamiłowania osobiste i gry;

9) środki masowego przekazu: prasa, radio, telewizja;

10) dojazdy i dojścia: związane z pracą, nauką, zajęciami domowymi (zakupy) i czasem wolnym, którego różne formy zestawiono pod numerami: 5-9.

Należy podkreślić, że $\mathrm{w}$ badaniach GUS zaznaczyła się tendencja do wskazywania coraz węższych grup zajęć: w 1969 r. - 46, 1976 r. - 49, 1984 r. 53, a w 1999 r. - 175 (!)

Połowa form (5) z przytoczonej klasyfikacji dotyczy czasu wolnego. Kryteriami rozgraniczenia czasu zajętego i czasu wolnego są według J. DuMAZEDIERA $(1962,1974)$ i J. PIĘTY (2008, s. 21-23):

1) dobrowolność (człowiek $z$ własnej woli lub pod namową otoczenia postanawia realizować coś, co sprawia przyjemność bezpośrednią albo przynosi satysfakcję w przyszłości jako wynagrodzenie trudów, np. w zakresie życia religijnego czy działalności społecznej);

2) bezinteresowność, czyli niezarobkowość (w odniesieniu do wypoczynku wywodzi się $\mathrm{z}$ celebrowania nieużytecznych materialnie czynności rozwijających osobowość ludzi - kiedyś głównie bogatych i uprzywilejowanych).

Według T. WOLAŃSKIEJ (1997, s. 17, 59) - przy kwalifikowaniu zajęć jako rekreacyjne zawsze warto zadać pytania: czy są one dobrowolne?, czy sprawiają przyjemność?, czy spełniają oczekiwania i zainteresowania?, jakie są motywy podejmowania danej czynności?, czy wpływają w sposób pozytywny na osobowość? Wspomniana autorka definiuje czas wolny jako czas, który pozostaje po wypełnieniu wszystkich obowiązków zawodowych, rodzinnych, domowych i związanych z obowiązkową nauką, który człowiek może przeznaczyć na zajęcia podejmowane dobrowolnie $\mathrm{w}$ celu spełnienia własnych zainteresowań.

Zagadnieniem najtrudniejszym, a jednocześnie najciekawszym w badaniach czasu są uwarunkowania struktury jego budżetu. Zdaniem autorki 
niniejszej pracy są one identyczne $\mathrm{z}$ czynnikami uczestnictwa $\mathrm{w}$ rekreacji. Zostały tu pogrupowane na podstawie pracy R. Winiarskiego - (1989, cyt. za: KIEŁBASIEWICZ-DROZDOWSKA, SIWIŃSKI, red. 2001, s. 20-21, WOLAŃSKA 1997, s. 18) oraz W. ALEJZIAKA (2000, s. 74-83) w sposób następujący (wyróżniono czynniki uwzględnione $\mathrm{w}$ przedmiotowym badaniu poprzez pytania ankiety - zał. 1):

1) czynniki biologiczne: stan zdrowia, poziom sprawności fizycznej, poziom wydolności fizycznej, typ budowy somatycznej;

2) czynniki psychiczne: osobowość, typ temperamentu, poziom inteligencji, postawa życiowa, struktura wartości, potrzeb i zainteresowań;

3) czynniki demograficzne: płeć, wiek, stan cywilny, liczba dzieci i stadium rozwoju rodziny, wielkość gospodarstwa domowego;

4) czynniki społeczne: wykształcenie, aktywność zawodowa, zawód charakter pracy, środowisko i pochodzenie społeczne, poziom urbanizacji miejsca zamieszkania;

5) czynniki ekonomiczne: poziom dochodów, wyposażenie gospodarstwa domowego $\mathbf{w}$ podstawowy sprzęt, urządzenia i środki lokomocji, dostępność zewnętrznych urządzeń, obiektów i oferty rekreacyjnej (zniżki, dotacje).

\section{Metoda badania budżetu czasu studentów, w tym ich czasu wolnego}

Autorka niniejszej pracy jesienią 2009, 2010 oraz 2012 r., prowadząc wykłady z "Pedagogiki czasu wolnego" zrealizowała badania: zagospodarowania czasu wolnego w wakacje danego roku oraz budżetu czasu w wybranych tygodniach jesiennej części roku akademickiego. W tym celu przygotowała ankiety i formularze, które miały bliźniacze numery. Ankieta służyła jako upoglądowienie treści wykładu na temat konstrukcji tego rodzaju narzędzia badawczego, a jednocześnie - po wypełnieniu, stanowiła materiał oddany do analizy bezpośrednio po zajęciach. Natomiast formularze były zabrane przez studentów do domu i wypełniane przez nich przez pełny tydzień od najbliższego poniedziałku do niedzieli. Większość studentów dziennych (dz) i zaocznych $(\mathrm{z})$ prowadziła samoobserwację tego samego dla danej grupy $(\mathrm{dz}, \mathrm{z})$ i danego roku $(2009,2010,2012)$ - jesiennego tygodnia pod względem gospodarowania czasem. 
W związku ze swoimi zainteresowaniami naukowymi i na potrzeby badań autorka skonstruowała ankietę, w której zamieściła swoje klasyfikacje czynników uczestnictwa w rekreacji (m.in. struktury zawodowej, warunków ekonomicznych, motywów) oraz klasyfikację zajęć rekreacyjnych. Zagadnienia te przybliżone zostały we wcześniejszych pracach (PISARSKA 2006, s. 2547, PISARSKA 2013, s. 21-35). W celu zaakcentowania jakościowej strony badań i zrozumienia kompatybilności ich dwóch części postanowiono zamieścić w niniejszym opracowaniu fragment - nigdzie jeszcze niepublikowanejankiety autorskiej (zał. 1) oraz formularz - zmodyfikowany w stosunku do przedstawionego w podręczniku J. PIĘTY (2008, s. 28-29).

Ze względu na logiczną kolejność wypełniania przez studentów najpierw ankiety, później formularza postanowiono w tym samym następstwie omówić pokrótce istotę tych dwóch etapów. Pierwsze siedem pytań ankiety (zał. 1) miało charakter metryczkowy związany z podstawowymi czynnikami gospodarowania czasem, w tym czasem wolnym. Jak wcześniej już wspomniano, autorka zaproponowała swoje klasyfikacje tychże czynników, podobnie jak motywów rekreacji, w tym motywów wyjazdów turystycznych (pytanie VIII ankiety). W pytaniu IX zawarta jest autorska klasyfikacja zajęć rekreacyjnych, o której poniżej. Załącznik zawiera tę część ankiety (pytania I-IX), która jest niezbędna do zrozumienia istoty badania budżetu czasu. Pozostałe pytania ankiety (X-XXVI) dotyczyły cech uczestnictwa w rekreacji (kiedy?, jak często?, na jak długo?, gdzie?, dokąd?, z kim?) oraz warunków materialno-przestrzennych do jej uprawiania (środek lokomocji, pokój do własnej dyspozycji, bliskość terenów i obiektów rekreacyjnych). Kilka pytań dotyczyło początków formacji prorekreacyjnej, stopnia niezależności w organizacji czasu oraz świadomości ograniczeń aktywności rekreacyjnej. Odpowiedzi na pytania XVI-XXVI pomogły wyjaśnić przyczyny poziomu aktywności rekreacyjnej studentów.

Odnośnie do klasyfikacji zajęć rekreacyjnych trzeba wyraźnie podkreślić, że żadna nie może być kompletna ze względu na nieprzebraną różnorodność form, co oczywiście nie powinno zniechęcać do podejmowania prób porządkowania tego typu zjawisk. Ludzie zawsze różnili się pod względem pomysłów na spędzanie czasu wolnego. Potrzebne zatem są klasyfikacje uniwersalne, uwzględniające szerokie grupy zajęć. Zawsze można poprosić respondentów o uzupełnienie ( $w$ ramach grup) informacji na temat tego - jakie konkretnie formy rekreacji uprawiają?

W autorskiej propozycji klasyfikacji wyznaczono dwie podstawowe linie podziału zajęć. Pierwsza linia wiąże się z obiektywną oceną aktywności 
ruchowej oraz z obiektywno-subiektywną oceną zaangażowania umysłowoemocjonalnego; przynosi ona podział na zajęcia aktywne i bierne. Druga dzieli je na te, które odbywają się w domu oraz poza domem:

I - zajęcia bierne (ruchowo; pozycja odbiorcy) w domu;

II - zajęcia bierne (jw.) poza domem;

III - zajęcia aktywne (ruchowo, ćwiczenie umiejętności, pozycja nadawcy) $\mathbf{w}$ domu;

IV - zajęcia aktywne (jw.) poza domem.

Należy tu wyjaśnić, że do zajęć biernych (ruchowo) autorka zalicza te, które odbywają się w pozycji spoczynkowej: leżącej i siedzącej, natomiast do zajęć aktywnych te, które łączą się z ruchem motorycznym (np. chodzeniem, bieganiem, skakaniem, tańcem, pływaniem). Co do niektórych czynności nie ma wątpliwości, jak je zaszeregować, przestrzegając wymienionej linii podziału. Istnieją jednakże takie, których przyporządkowanie jest trudniejsze ze względu na zajmowanie pozycji siedzącej, a jednocześnie ćwiczenie pewnych umiejętności (np. gry na instrumencie) lub twórczy charakter (pisanie pamiętnika). W takich przypadkach autorka zachęca do kwalifikowania zajęć jako aktywnych ze względu na doniosłość każdego przejawu zaangażowania duchowo-umysłowego dla rozwoju osobowości człowieka. Konieczne jednak jest $\mathrm{w}$ tym względzie uproszczenie, polegające na rozróżnieniu tego, czy ankietowany, uczestnicząc w rekreacji, odgrywa rolę nadawcy czy odbiorcy pewnych wartości (PISARSKA 2006, s. 39).

Większość studentów, wypełniając w powolnym tempie ankietę, poznało przybliżony w niej podział zajęć rekreacyjnych, co ułatwiło im kwalifikowanie czynności wolnoczasowych przy badaniu budżetu czasu w domu. Poniżej przedstawiono oryginalny formularz (studentki nr 3) służący do tego celu (z objaśnieniem); był on jednokartkowy - dwustronny (tu wyróżniony mniejszą czcionką).

Tygodniowy budżet czasu studenta III roku kierunku „turystyka i rekreacja”

\begin{tabular}{|l|c|c|c|c|c|c|c|c|c|c|}
\hline Czynność ${ }_{, \prime}{ }^{\prime \prime}$ & Pn & Wt & Śr & Cz & Pt & Sb & N & $\sum$ Ya & $\begin{array}{c}Y^{\prime} \mathrm{a}= \\
\Sigma \mathrm{a} / 7\end{array}$ & $\begin{array}{c}\text { Y'a/ } \\
24 \times 100 \%\end{array}$ \\
\hline \multicolumn{1}{|c|}{$[1]$} & {$[2]$} & {$[3]$} & {$[4]$} & {$[5]$} & {$[6]$} & {$[7]$} & {$[8]$} & {$[9]$} & {$[10]$} & {$[11]$} \\
\hline Fizjologia - razem & $\mathbf{1 2 , 0}$ & $\mathbf{9 , 0}$ & $\mathbf{9 , 5}$ & $\mathbf{7 , 5}$ & $\mathbf{8 , 0}$ & $\mathbf{1 0 , 5}$ & $\mathbf{1 1 , 0}$ & $\mathbf{6 7 , 5}$ & $\mathbf{9 , 6}$ & $\mathbf{4 0 , 0}$ \\
\hline - sen & 9,0 & 7,0 & 7,5 & 5,5 & 6,0 & 8,0 & 9,0 & 52,0 & 7,4 & 30,8 \\
\hline - higiena & 1,0 & 1,0 & 1,0 & 1,0 & 1,0 & 1,5 & 1,0 & 7,5 & 1,1 & 4,6 \\
\hline - jedzenie posiłków & 2,0 & 1,0 & 1,0 & 1,0 & 1,0 & 1,0 & 1,0 & 8,0 & 1,1 & 4,6 \\
\hline Praca zarobkowa & $\mathbf{0 , 0}$ & $\mathbf{0 , 0}$ & $\mathbf{8 , 0}$ & $\mathbf{0 , 0}$ & $\mathbf{0 , 0}$ & $\mathbf{4 , 0}$ & $\mathbf{0 , 0}$ & $\mathbf{1 2 , 0}$ & $\mathbf{1 , 7}$ & $\mathbf{7 , 0}$ \\
\hline
\end{tabular}




\begin{tabular}{|l|c|c|c|c|c|c|c|c|c|c|}
\hline$[1]$ & {$[2]$} & {$[3]$} & {$[4]$} & {$[5]$} & {$[6]$} & {$[7]$} & {$[8]$} & {$[9]$} & {$[10]$} & {$[11]$} \\
\hline Nauka - razem & $\mathbf{0 , 5}$ & $\mathbf{5 , 5}$ & $\mathbf{2 , 0}$ & $\mathbf{6 , 0}$ & $\mathbf{5 , 5}$ & $\mathbf{1 , 0}$ & $\mathbf{1 , 0}$ & $\mathbf{2 1 , 5}$ & $\mathbf{3 , 1}$ & $\mathbf{1 2 , 9}$ \\
\hline - poza domem & 0,0 & 4,5 & 0,0 & 3,0 & 4,5 & 0,0 & 0,0 & 12,0 & 1,7 & 7,1 \\
\hline - w domu & 0,5 & $\mathbf{1 , 0}$ & 2,0 & 3,0 & 1,0 & 1,0 & 1,0 & 9,5 & 1,4 & 5,8 \\
\hline Zajęcia domowe & $\mathbf{2 , 0}$ & $\mathbf{1 , 5}$ & $\mathbf{1 , 0}$ & $\mathbf{1 , 5}$ & $\mathbf{1 , 5}$ & $\mathbf{1 , 5}$ & $\mathbf{2 , 0}$ & $\mathbf{1 1 , 0}$ & $\mathbf{1 , 6}$ & $\mathbf{6 , 7}$ \\
\hline - prace porządkowe & 0,5 & $\mathbf{1 , 0}$ & 0,5 & 1,0 & 0,5 & 1,0 & 1,0 & 5,5 & 0,8 & 3,3 \\
\hline $\begin{array}{c}\text { - przygotowanie } \\
\text { posiłków }\end{array}$ & 1,5 & 0,5 & 0,5 & 0,5 & 1,0 & 0,5 & 1,0 & 5,5 & 0,8 & 3,3 \\
\hline - inne & 0,0 & 0,0 & 0,0 & 0,0 & 0,0 & 0,0 & 0,0 & 0,0 & 0,0 & 0,0 \\
\hline Dojazdy - razem & $\mathbf{0 , 0}$ & $\mathbf{2 , 5}$ & $\mathbf{1 , 5}$ & $\mathbf{2 , 5}$ & $\mathbf{3 , 0}$ & $\mathbf{1 , 5}$ & $\mathbf{0 , 0}$ & $\mathbf{1 1 , 0}$ & $\mathbf{1 , 6}$ & $\mathbf{6 , 7}$ \\
\hline $\begin{array}{c}\text { - do uczelni i z pow- } \\
\text { rotem }\end{array}$ & 0,0 & 2,0 & 0,0 & 2,0 & 2,0 & 0,0 & 0,0 & 6,0 & 0,9 & 3,8 \\
\hline $\begin{array}{c}\text { - do pracy i z pow- } \\
\text { rotem }\end{array}$ & 0,0 & 0,0 & 1,5 & 0,0 & 0,0 & 1,5 & 0,0 & 3,0 & 0,4 & 1,7 \\
\hline $\begin{array}{c}\text { - na zakupy i z pow- } \\
\text { rotem }\end{array}$ & 0,0 & 0,5 & 0,0 & 0,5 & 1,0 & 0,0 & 0,0 & 2,0 & 0,3 & 1,3 \\
\hline $\begin{array}{c}\text { - do miejsc rekreacji } \\
\text { i z powrotem }\end{array}$ & 0,0 & 0,0 & 0,0 & 0,0 & 0,0 & 0,0 & 0,0 & 0,0 & 0,0 & 0,0 \\
\hline Czas wolny - razem & 9,5 & 5,5 & 2,0 & 6,5 & 6,0 & 5,5 & 10,0 & 45,0 & 6,4 & 26,7 \\
\hline I - bierne w domu & 4,0 & 2,0 & 1,0 & 3,0 & 3,0 & 2,0 & 6,0 & 21,0 & 3,0 & 12,5 \\
\hline II - bierne poza domem & 1,5 & 1,0 & 0,5 & 0,5 & 0,5 & 0,55 & 1,0 & 5,5 & 0,8 & 3,3 \\
\hline III - aktywne w domu & 0,5 & 0,5 & 0,0 & 1,0 & 0,5 & 1,0 & 1,0 & 4,5 & 0,6 & 2,6 \\
\hline $\begin{array}{c}\text { IV - aktywne poza } \\
\text { domem }\end{array}$ & 3,5 & 2,0 & 0,5 & 2,0 & 2,0 & 2,0 & 2,0 & 14,0 & 2,0 & 8,3 \\
\hline
\end{tabular}

\section{Objaśnienia:}

Y a - czas wykonywania czynności „a" $\mathrm{w}$ danym dniu przez daną osobę w godzinach wypełniamy z dokładnością do kwadransa - 15 min - 0, 25 godz.; 30 min - 0,5 godz.; 45 min - 0,75 godz., np. 1g; 2,25 g; 3,5 g; 2,45 g - najpierw wpisujemy ile czasu zajęła nam forma szczegółowa, a następnie dodajemy formy szczegółowe, aby wpisać sumę przy formie głównej (zaznaczonej pogrubioną czcionką). Uwaga - w danym dniu suma form głównych (w pionie) musi wynosić 24 godziny.

$\Sigma$ Ya - suma dziennych wymiarów czasu przeznaczonych na czynność "a”, czyli w badanym tygodniu, tj. od Poniedziałku (...) do Niedzieli (...). (w godzinach, np. sen ok. 50 godz.).

Y'a - przeciętny czas wykonywania czynności ",a" $\mathrm{w}$ badanym tygodniu = $\Sigma \mathrm{Ya} / 7$, np. sen 50/7 $=7,1 \operatorname{godz}$.

Y'a/24 x 100\% - udział procentowy przeciętnego czasu wykonywania czynności "a" w wymiarze doby ( 24 godz.), np. sen 7,1/24 x 100\%=0,296 x 100\%=29,6\% . Uwaga, dodajemy formy szczegółowe, aby otrzymać udział procentowy formy głównej, zapisany z dokładnością do 0,1\%. Suma udziałów procentowych form głównych (zaznaczonych pogrubioną czcionką) musi wynosić w pionie $100 \%$ !

Ad. Czas wolny: bierne ruchowo, tzn. w pozycji leżącej albo siedzącej; bierne intelektualnie, tzn. w pozycji biorcy, odbiorcy, słuchacza, widza, kibica, gościa..., aktywne ruchowo (spacerowanie, bieganie, jeżdżenie...); aktywne intelektualnie i społecznie, tzn. postawa dawcy, nadawcy albo ćwiczenie umiejętności...

Źródło: opracowanie autorki wykonane na podstawie własnych badań. 
Autorka pragnie podkreślić, że gwarantując studentom anonimowość była świadoma, iż trudno będzie liczyć na skrupulatność w wypełnieniu przez nich formularzy budżetu czasu. Niektórzy studenci zapominali o dacie rozpoczęcia samoobserwacji i rozpatrywali inny tydzień niż większość kolegów. Inni wywiązali się z terminu, ale popełnili błędy w obliczeniach, a nieliczni zagubili formularze $\mathrm{z}$ im przypisanymi numerami (bliźniaczymi z numerami ich ankiet), więc zaliczali zadanie, ale $\mathrm{z}$ dużym minusem, ponieważ taki materiał nie nadawał się właściwie do dalszej analizy.

Skala badań pokazana jest w tab. 1 .

Tab. 1. Liczba badanych studentów III roku TiR w WSE-I => AFiBV

\begin{tabular}{|l|c|c|c|}
\hline \multirow{2}{*}{ Rok badania i nazwa uczelni (w tym samym gmachu) } & \multicolumn{3}{|c|}{ Liczba studentów } \\
\cline { 2 - 4 } & dziennych & zaocznych & razem \\
\hline 2009 - Wyższa Szkoła Ekonomiczno-Informatyczna (WSE-I) & 36 & 85 & 121 \\
\hline 2010 - Wyższa Szkoła Ekonomiczno-Informatyczna (WSE-I) & 22 & 94 & 116 \\
\hline 2012 - Akademia Finansów i Biznesu Vistula (AFiBV) & 31 & 48 & 79 \\
\hline
\end{tabular}

Źródło: opracowanie autorki na podstawie badań własnych.

Badania z 2011 r. (łącznie 60 osób) nie zostały tu uwzględnione z powo$\mathrm{du}$ koniecznej rezygnacji $\mathrm{z}$ rozdawania formularzy do badania budżetu czasu studentów.

\section{Budżety czasu wybranych studentów - studia przypadków z odniesieniem do ich tła}

W związku z zagwarantowaniem studentom anonimowości nierealne było dokładne sprawdzanie prawidłowości wypełnienia formularzy przy ich odbiorze. Skutkowało to koniecznością odrzucenia wielu z nich ze względu na niestaranność wypełnienia (pokolenia dysgrafików), błędy w dodawaniu i dzieleniu danych oraz brak zaokrąglania liczb do jednego miejsca po przecinku. Doboru formularzy do dalszej analizy dokonano na zasadzie żmudnych porównań cech jakościowych i odnoszenia struktury budżetów do tła grupy w układzie: dzienni (dz), zaoczni (z) w danym roku. Efektem końcowym był wybór sześciu formularzy najbardziej typowych dla danej grupy studentów; posłużyły one do przeprowadzenia studium przypadków odnośnie do struktury budżetu czasu studentów, w tym ich czasu wolnego. 
Tab. 2. Budżety czasu wybranych studentów III roku TiR (w\%)

\begin{tabular}{|l|c|c|c|c|c|c|c|c|c|c|c|c|}
\hline $\begin{array}{c}\text { Nr, } \\
\text { tryb }\end{array}$ & A.z & W.e & Fiz. & Pr. & Nau. & Z.d & Doj. & Cz.w & I & II & III & IV \\
\hline \multicolumn{10}{|c|}{ Rok 2009} \\
\hline $1 \mathrm{dz}$ & d & bdb. & 37,5 & 8,0 & 18,0 & 17,0 & 7,5 & 12,0 & 6,0 & 1,0 & 1,5 & 3,5 \\
\hline $2 \mathrm{z}$ & e & db. & 30,9 & 21,0 & 8,0 & 9,2 & 8,8 & 22,1 & 7,9 & 5,2 & 1,1 & 7,9 \\
\hline \multicolumn{10}{|c|}{ Rok 2010} \\
\hline $3 \mathrm{dz}$ & d & db. & 40,0 & 7,0 & 12,9 & 6,7 & 6,7 & 26,7 & 12,5 & 3,3 & 2,6 & 8,3 \\
\hline $4 \mathrm{z}$ & e & dst. & 45,4 & 23,8 & 7,9 & 9,2 & 5,8 & 7,9 & 4,6 & 0,4 & 1,7 & 1,2 \\
\hline \multicolumn{10}{|c|}{ Rok 2012} \\
\hline $5 \mathrm{dz}$ & d & db. & 47,0 & 2,9 & 11,6 & 12,7 & 6,8 & 19,0 & 11,2 & 1,6 & 2,5 & 3,7 \\
\hline $6 \mathrm{z}$ & e & dst. & 37,5 & 26,7 & 12,5 & 5,0 & 8,7 & 9,6 & 5,4 & 1,7 & 0,8 & 1,7 \\
\hline \multicolumn{10}{|c|}{ Wartości średnie } \\
\hline t. dz. & x & x & 41,5 & 6,0 & 14,2 & 12,1 & 7,0 & 19,2 & 9,9 & 2,0 & 2,2 & 5,2 \\
\hline t. z. & x & x & 37,9 & 23,8 & 9,5 & 7,8 & 7,8 & 13,2 & 6,0 & 2,4 & 1,2 & 3,6 \\
\hline
\end{tabular}

Oznaczenia: dz - studenci dzienni, z - studenci zaoczni; A.z - aktywność zawodowa: d - praca dorywcza, e - praca na etacie; W.e - warunki ekonomiczne; Fiz. - fizjologia, Pr. - praca, Nau. - nauka, Z.d - zajęcia domowe, Doj. - dojazdy, Cz.w - czas wolny: I - zajęcia bierne w domu, II - zajęcia bierne poza domem, III - zajęcia aktywne w domu, IV - zajęcia aktywne poza domem.

Źródło: opracowanie własne na podstawie badań.

Próbę wyjaśnienia czynników różnicujących budżety czasu sześciu wybranych przypadków należy rozpocząć od wykazania ich reprezentatywności dla grup i roczników, do których należały. Jest to możliwe dzięki powołaniu się na dokładne obliczenia przedstawione $\mathrm{w}$ dwóch raportach $\mathrm{z}$ badań (PISARSKA 2010, s. 1-28, 2012, s. 1-32). Następnie przytoczone zostaną maksymalne (maks.), minimalne (min.) oraz uśrednione (dla danego trybu studiów: dzienne - dz, zaoczne - z) wartości procentowe przeciętnego czasu wykonywania czynności „a" przez osoby spod numerów 1-6 w wymiarze doby (Y'a/24 x 100\%). Zdecydowano się na wybór:

1) osób z województwa mazowieckiego, ponieważ stąd pochodziło maks. 100\% studentów dziennych w 2009 r. (dz2009), a min. 81,8\% studentów zaocznych w 2010 r. (z2010);

2) osób zamieszkałych $w$ miastach i wsiach różnej wielkości; ze stolicy pochodziło maks. $66,7 \%$ dz2009, a min. $38,8 \%$ z2009;

3) samych kobiet, ponieważ dominowały one we wszystkich grupach, stanowiąc maks. - 63\% z2010, a min. 58,3\% dz2009; 
4) samych panien, ponieważ osoby stanu wolnego dominowały we wszystkich grupach - od maks. 100\% dz2010 do min. 79,8\% z2010 (w tej grupie osoby w wolnych związkach stanowiły 10,6\%);

5) osób bezdzietnych, ponieważ ich dominacja była wyraźna, wynosząc maks. 100\% dz2010, a min. 90,4\% z2010;

6) samych aktywnych zawodowo (na etacie i dorywczo), ponieważ tacy ludzie dominowali, stanowiąc maks. $89,4 \%$ z2009 i z2010, a min. $61,1 \%$ dz2009;

7) różnie oceniających swe warunki ekonomiczne; najpowszechniej oceniono je jako: bardzo dobre - 55,6\% dz2009; dobre - 51,8\% z2009 (40,9\% dz2010); dostateczne - 32,9\% z2009 (27,7\% z2010).

$\mathrm{Z}$ analizy struktur budżetów czasu zawartych w tab. 2. wynika, że:

A - największe zróżnicowanie występuje w udziałach pracy zawodowej; ich amplituda wynosi 23,8\% (maks. dla nr $6-26,7 \%$, min. dla nr $5-2,9 \%$ ). Różnica wartości uśrednionych dla studentek zaocznych i dziennych jest mniejsza $(17,8 \%)$, ale największa wśród wszystkich rodzajów zajęć. Stanowi to potwierdzenie wyników M. BOMBOL i A. DĄBROWSKIEJ (2003, s. 6-7), że długość pracy wyraźnie różnicuje struktury budżetu czasu wielu grup społecznych;

B - duże zróżnicowanie dotyczy czasu wolnego i fizjologii; amplituda dla czasu wolnego wynosi 18,8\% (maks. dla nr 3 - 26,7\%, min. dla nr $4-7,9 \%$ ), a dla fizjologii 16,1\% (maks. dla nr 5 - 47\%, min. dla nr 2 - 30,9\%). Różnica wartości uśrednionych dla trybów: dziennego i zaocznego równa się 6\% odnośnie do czasu wolnego i 3,6\% - odnośnie do fizjologii, co świadczy o tym, że potrzeba snu jako głównego jej składnika ma charakter indywidualny;

C - mniejsze zróżnicowanie zachodzi w odniesieniu do nauki (amplituda wynosi 10,1\%, różnica średnich 4,7\%) oraz zajęć domowych (amplituda $12 \%$, różnica średnich $4,3 \%$ );

D - najmniejsze zróżnicowanie zaznacza się w odniesieniu do dojazdów, co wynika zapewne $\mathrm{z}$ faktu posiadania samochodów przez $5 / 6$ wybranych osób, ale jest dosyć zaskakujące ze względu na różnorodność miejscowości ich zamieszkania.

Reasumując należy stwierdzić, że wszystkie elementy struktury budżetu czasu są ze sobą ściśle powiązane. Istnieje sprzężenie zwrotne między trybem studiów a aktywnością zawodową. Studia dzienne raczej wykluczają pracę na etat; studenci dzienni pracują przeważnie dorywczo po parę godzin $\mathrm{w}$ środku tygodnia albo dłużej $\mathrm{w}$ weekendy. $\mathrm{Z}$ kolei studenci zaoczni, pracując $z$ reguły po 8 godz. - przez pięć dni w tygodniu, starają się odpoczywać przynajmniej przez jeden dzień poza „zjazdowymi” weekendami. 
Na podstawie przeglądu (nie tylko wybranych) formularzy można stwierdzić, że studenci ograniczają zainteresowanie nauką do uczestnictwa $\mathrm{w}$ zajęciach, natomiast w związku z mniejszym udziałem ćwiczeń - rzadko studiują indywidualnie w bibliotekach i w domu. Realia są takie, że w sytuacji aktywności zawodowej, braku dokładnego harmonogramu dnia, słabszej motywacji, wynikającej najczęściej ze zmęczenia (potęgowanego nadużywaniem mediów elektronicznych) - nie mają kiedy się uczyć, a doba ma zawsze tylko 24 godziny. Autorka zauważa wyraźny brak uczenia się kosztem snu, co byłoby nawykiem pozytywnym przy założeniu, że studenci w ciągu dnia efektywnie gospodarowaliby swym czasem; $4 / 6$ wybranych osób uznało, że wypełnienie formularza przyczyni się do oszczędniejszego zarządzania czasem (a taki był - poza naukowym - cel badania).

Prezentowana tu metoda badania budżetu czasu pozwala bliżej ocenić strukturę czasu wolnego. Na podstawie obliczeń danych z tab. 2 skonstruowano tab. 3.

Tab. 3. Struktura czasu wolnego pod względem aktywności form i miejsca ich realizacji (w\%)

\begin{tabular}{|c|c|c|c|c|}
\hline \multirow{2}{*}{$\mathrm{Nr}$} & \multicolumn{2}{|c|}{ Rodzaj form } & \multicolumn{2}{c|}{ Miejsce realizacji } \\
\cline { 2 - 5 } & bierne & aktywne & w domu & poza domem \\
\cline { 2 - 5 } & I + II & III + IV & I + III & II + IV \\
\hline 1 & 58,3 & 41,7 & 62,5 & 37,5 \\
\hline 2 & 59,3 & 40,7 & 40,7 & 59,3 \\
\hline 3 & 59,2 & 40,8 & 56,5 & 43,5 \\
\hline 4 & 63,3 & 36,7 & 79,7 & 20,3 \\
\hline 5 & 67,4 & 32,6 & 72,1 & 27,9 \\
\hline 6 & 74,0 & 26,0 & 64,6 & 35,4 \\
\hline
\end{tabular}

Źródło: obliczenia własne na podstawie badań.

Na podstawie tab. 3. widać, że wszystkie wybrane osoby preferowały formy bierne $(\mathrm{I}+\mathrm{II})$ i w dodatku, $\mathrm{z}$ wyjątkiem numeru 2 - w domu. $\mathrm{Z}$ dużą dozą dystansu, ze względu na obliczenia budżetów czasu wolnego tylko dla sześciu studentek, można stwierdzić, że im mniejsza zamożność, tym większy udział biernych form spędzania czasu wolnego i większa zasiedziałość $\mathrm{w}$ domu. Studenci mniej zamożni powinni nastawić się na plenerowe formy rekreacji, wykorzystując $\mathrm{w}$ najbliższej okolicy urządzone tereny zieleni osiedlowej oraz otwarte tereny okołoosiedlowe. Warto byłoby korzystać z tych obiektów kulturalnych i sportowych, które uwzględniają zniżki dla studentów. 
Pomimo rozpatrzenia wielu elementów, które mogłyby wyjaśnić strukturę czasu wolnego, nie znaleziono wyraźnych zależności. Chociaż badane osoby różniły się pod względem zamożności (tab. 2), to miały podobne warunki w zakresie:

1) posiadania auta, roweru i własnego pokoju;

2) bliskości stacji komunikacji dalekobieżnej i przystanku komunikacji miejskiej;

3) istnienia warunków do uprawiania rekreacji, tzn. bliskości terenów otwartych i zielonych oraz obiektów kulturalnych i sportowych.

Oczywiście w skali całych grup stwierdzono wpływ wymienionych elementów na sposób spędzania czasu wolnego studentów, o czym autorka wspomniała w swych raportach z badań (PISARSKA 2010, s. 1-28, 2012, s. 1-32).

\section{Postulaty doskonalenia niniejszego podejścia badawczego}

W badaniach czasu, w tym czasu wolnego, równie ważne są trzy grupy zagadnień: wymiar, struktura oraz treść. Oznacza to, że nie tyle rozmiar czasu wolnego, co rodzaj wykonywanych $\mathrm{w}$ jego ramach czynności świadczy o postępie społecznym. W związku $\mathrm{z}$ tym, jak podkreśla T. WOLAŃSKA (1997, s. 13-14) - budżet czasu jest jednym z mierników zachowań ludzkich, w tym dotyczących czasu wolnego.

Autorka niniejszego opracowania twierdzi, że niezależnie od ustroju, badania tego typu powinny być prowadzone systematycznie i w oparciu o zbliżoną metodologię $\mathrm{w}$ celu porównywania struktury rodzajowej i przestrzennej zachowań rekreacyjnych różnych grup społecznych, ogólnie w kraju i w jego poszczególnych regionach.

Zaprezentowana tu metoda badania budżetu czasu jest pracochłonna, ale zarazem efektywna. Jej zalety polegają na możliwości określenia:

1) przeciętnej struktury zajęć w wymiarze doby (w\%);

2) udziału form aktywnych i biernych czasu wolnego oraz miejsc ich realizacji w ujęciu generalnym ( $w$ domu i poza nim); te dwie linie podziału są niezwykle ważne dla urealnienia oceny popytu i podaży w zakresie rekreacji, co powinno zainteresować ekonomistów;

3) średniej ilości czasu w dniu powszednim, w soboty i niedziele; tu tego nie obliczono, aczkolwiek najprawdopodobniej wartości te dla badanych studentów są niższe niż przytoczone przez J. MARAKA 
(2000, s. 130, 132) i J. WYRZYKOWSKIEGO (2005, s. 210, 212). Według badań tych naukowców studenci wrocławscy w latach 1998-1999 dysponowali przeciętnie 5,5 godz. czasu wolnego w dniu powszednim, 6 godz. 48 min. w soboty i 7 godz. 26 min. w niedziele.

Trudności metody badania czasu wolnego zaprezentowanej przez autorkę wiążą się z zadaniem zmobilizowania respondentów do solidnej samoobserwacji zajęć oraz poprawnego ich podliczenia w sytuacji konieczności zagwarantowania anonimowości. Wartość wyników tych badań wzrosłaby po napisaniu programu komputerowego pozwalającego na obliczenie różnych korelacji.

Zdaniem autorki - przy humanistycznym podejściu do badań nad czasem wolnym - wysiłki należy skupić nad takimi istotnymi sprawami, jak jego ogólny sens oraz przyczyny i skutki dominujących sposobów jego spędzania w danym środowisku. Nie należy obawiać się pytań wprost np. o nadrzędne wartości w życiu człowieka. To przecież sfera tego wszystkiego, co dla nas jest najważniejsze, powinna decydować, a więc i odzwierciedlać się w czynnościach czasu wolnego.

Badania budżetu czasu i zagospodarowania czasu wolnego mają bardzo dużą przydatność społeczną. Powinny służyć do opracowywania diagnoz, zaleceń i prognoz na potrzeby prowadzenia polityki społecznej oraz organizacji kultury, turystyki i sportu. Istnieje głęboki sens ich prowadzenia w odniesieniu do studentów kierunku „turystyka i rekreacja” jako przyszłych organizatorów czasu wolnego.

Wydawać by się mogło, że sam wzrost ilości czasu wolnego pociąga za sobą większą różnorodność zajęć spełnianych w jego zakresie. Tymczasem $z$ różnych badań, nawet dotyczących studentów czy grup dobrze sytuowanych wynika, że ludzie ograniczają się do zachowań stereotypowych pod tym względem. Przyczyny w niektórych przypadkach są oczywiste - ci, którzy mają wiedzę i motywacje nie mogą korzystać z pewnych form ze względu na brak finansów. Wielu z tych, którzy mają środki, preferuje najprostsze bierne formy, czy to ze względu na brak orientacji w możliwościach, czy to z powodu przemęczenia albo lenistwa.

Autorka niniejszego opracowania, podobnie jak M. BOMBOL i A. DĄBROWSKA (2003, s. 187), apeluje o większe zaangażowanie szkół wszystkich szczebli oraz środków społecznego przekazu w propagowanie zdrowego stylu życia. Istnieje prawdopodobieństwo, że upowszechnianie wyników badań na temat budżetu czasu, w tym czasu wolnego, zwiększy świadomość konieczności wartościowego spędzania czasu. W celu profilaktyki zdrowot- 
nej zespoły specjalistów powinny tworzyć i popularyzować wzorcowe budżety czasu dla uczniów poszczególnych poziomów kształcenia, dla wielu grup zawodowych, dla emerytów czy osób z różnymi rodzajami niepełnosprawności.

\section{Bibliografia}

AlEJZIAK W., 2000, Turystyka w obliczu wyzwań XXI wieku, Albis, Kraków.

BOMBOL M., DĄBROWSKA A., 2003, Czas wolny. Konsument. Rynek. Marketing, Wyd. K.E. Liber, Warszawa.

DUMAZEDIER J., 1962, Vers une civilisation du loisier, Edition du Seul, Paris.

DUMAZEDIER J., 1974, Sociologie empirique du loisier, Edition du Seul, Paris.

KIEŁBASIEWICZ-DROZDOWSKA I., 2001, Zarys rozwoju refleksji teoretycznej nad problematyka rekreacji, [w:] I. Kiełbasiewicz, W. Siwiński (red.), Teoria i metodyka rekreacji (zagadnienia podstawowe), AWF, Poznań.

MARAK J., 2000, Budżet czasu wolnego i jego zagospodarowanie przez studentów Wroctawia, [w:] J. Wyrzykowski (red.), Studia nad czasem wolnym mieszkańców dużych miast Polski i jego wykorzystaniem na rekreacje ruchową i turystykę, AWF, Wrocław.

PIĘTA J., 2008, Pedagogika czasu wolnego, Wyższa Szkoła Ekonomiczna, Warszawa.

PISARSKA B., 2006, Propozycja klasyfikacji wybranych czynników uczestnictwa w rekreacji na tle literatury przedmiotu, [w:] Problemy rozwoju turystyki na Wileńszczyźnie, Mazowszu, Podlasiu, Wotyniu i Podolu, Roczniki Wydziału Nauk Humanistycznych, t. VIII, Wydawnictwa WSTiJO i SGGW, Warszawa - Lwów, Żytomierz, s. 25-47.

PISARSKA B., 2010, Zagospodarowanie czasu wolnego w wakacje 2009 r. przez studentów III roku turystyki i rekreacji Wyższej Szkoty Ekonomiczno-Informatycznej (WSE-I) w Warszawie; Raport z badań, WSE-I, Warszawa, s. 1-28.

PISARSKA B., 2012, Zagospodarowanie czasu wolnego w wakacje 2010 i 2011 r. przez studentów turystyki i rekreacji WSEI = Uczelni Vistula oraz Wyższej Szkoty Turystyki $i$ Rekreacji w Warszawie, Raport z badań, Uczelnia Vistula, Warszawa, s. 1-32.

PISARSKA B., 2013, W drodze do uniwersalności klasyfikacji form rekreacji, w tym turystyki, [w:] B. Włodarczyk, R. Wiluś, J. Wojciechowska (red.), Nowe - stare formy turystyki w przestrzeni, ser. „Warsztaty z Geografii Turyzmu", t. 3, Wyd. UŁ, Łódź, s. 21-35.

SŁABY T., 2000, Rekreacja i turystyka w świetle GUS-owskich badań budżetów czasu, [w:] J. Wyrzykowski (red.), Studia nad czasem wolnym mieszkańców dużych miast Polski i jego wykorzystaniem na rekreacje ruchową i turystykę, AWF, Wrocław.

TOCZEK-WERNER S., SOŁTYSIK M., 1997, Aktualny stan badań nad czasem wolnym mieszkańców dużych miast polskich, [w:] P. Zarzycki (red.), Koncepcja badań nad czasem wolnym mieszkańców Wroctawia i jego wykorzystaniem na rekreację i turystykę. Materiaty seminaryjne, AWF, Wrocław.

TOCZEK-WERNER S., SOŁTYSIK M., 2006, Kierunki i zasięg polskich badań nad czasem wolnym i jego wykorzystaniem na rekreacje i turystyke, [w:] J. Krupa., J. Biliński (red.), Turystyka w badaniach naukowych. Prace przyrodnicze i humanistyczne, Wyższa Szkoła Informatyki i Zarządzania, Rzeszów, s. 397-428.

WNUK-LIPIŃSKI E., 1972, Praca $i$ wypoczynek w budżecie czasu, Instytut Filozofii i Socjologii PAN, Ossolineum, Warszawa.

WOLAŃSKA T., 1997, Leksykon: sport dla wszystkich - rekreacja ruchowa, AWF, Warszawa.

WYRZYKOWSKI J., 2005, Czas wolny mieszkańców Wroctawia i jego wykorzystanie, „Turyzm”, 15/ 1-2, s. 209-215. 


\section{Ankieta na temat zagospodarowania czasu wolnego studentów III r. TiR w wakacje br.}

I Miejsce zamieszkania: woj.

1) wieś mała 0-100 osób

4) miasteczko 2001-10 000

7) miasto duże 100
2) wieś średnia 101-1000

5) miasto małe $10001-50000$ powiat

3) wieś duża $1001-2000$

6) miasto średnie 50 001-100 000

II a Płeć:

1) kobieta

2) mężczyzna

II b Wiek: $\quad$ 1) $19,1-21$

2) $21,1-23$

3) $23,1-25$

4) powyżej 25 lat

\section{Stan: a) cywilny}

1) panna, kawaler

2) mężatka, żonaty

3) rozwiedziona (y)

4) wdowa, wdowiec

5) tzw. wolny związek

\section{b) rodzinny \\ c) wiek dzieci}

1) bezdzietni

2) 1-2 dzieci

3) 3-5 dzieci
1) 0,0-3 najmłodsze

2) 3,1-6 przedszkolne

3) 6,1-10 objęte nauczaniem początkowym

IV Profil wykształcenia średniego:
1) liceum ogólnokształcące
3) technikum
2) liceum
4) studium policealne

V Aktywność zawodowa i wykonywany zawód:

a) nie pracuję wcale

b) pracuję dorywczo:

c) pracuję na etacie:

1) pracownicy rolnictwa, ogrodnictwa, sadownictwa i leśnictwa [robotnicy, właściciele pracujący fizycznie, zarządcy i właściciele nie pracujący fizycznie]

2) pracownicy zakładów produkcyjnych w zakresie budownictwa, przemysłu i rzemiosła [robotnicy, pracownicy techniczno-inżynieryjni, kadra zarządzająca ( $w$ tym właściciele na etacie)]

3) pracownicy handlu hurtowego i detalicznego [obsługa ludności, kadra zarządzająca (w tym właściciele na etacie)]

4) pracownicy usług dla firm i ludności [obsługa ludności i kadra zarządzająca (w tym właściciele na etacie)

5) urzędnicy oraz średni i niższy personel służb państwowo-społecznych

6) inne zawody (duchowieństwo, artyści)

VI Warunki ekonomiczne respondentów $i$ ich rodzin (zamożność):

1) skrajna bieda;

2) bieda;

3) warunki dostateczne [jedno lub więcej źródeł utrzymania (pensji min. 1276 zł lub in.) gwarantujące minimum socjalne dla każdego członka rodziny (2009 r. - 701,47 zł)];

4) warunki dobre [jedno lub więcej źródeł utrzymania (pensji lub in.) w wysokości około średniej krajowej miesięcznej pensji (2009 r. - 3185,61 zł)];

5) warunki bardzo dobre [jedno lub więcej źródeł utrzymania (pensji lub in.) w wysokości znacznie powyżej średniej krajowej miesięcznej pensji (2009 r. > 3185,61 zł)];

6) warunki wyjątkowo bardzo dobre [lepsze niż określone powyżej = obfitość].

VII Stan zdrowia:
1) bardzo zły
2) słaby
3) dostateczny
4) dobry
5) bardzo dobry

VIII Motywy rekreacji, w tym wyjazdów turystycznych

1) zdrowotne:

a) profilaktyka psycho-fizyczna (odpoczynek od czegoś, kogoś; wypoczynek aktywny i bierny); 
b) leczenie psycho-fizyczne (rehabilitacja i terapia uzdrowiskowa);

c) szczególne podnoszenie sprawności w zakresie określonej formy turystyki kwalifikowanej lub sportu amatorskiego.

2) poznawcze:

a) poznawanie innego człowieka, grupy ludzi, pewnych społeczności; odwiedzanie krewnych i znajomych;

b) poznawanie miejsc, obiektów i krajobrazów, czyli materialnych tworów natury i kultury;

3) kontemplacyjne (poznawanie siebie, sacrum poprzez piękno natury, twórczość, pielgrzymowanie, rekolekcje);

4) rozrywkowe - ludyczne (związane z potrzebą szybkiego odreagowania stresów):

a) w zakresie normalnym (spotkania i zabawy towarzyskie, w tym rodzinne);

b) w zakresie poza normą (czyli łącznie z prowokowaniem innych i zakłócaniem ich spokoju);

5) prestiżowe (studia, kongresy, praca społeczna, ale także naśladowanie innych - snobizm; uleganie modzie);

6) inne (szukanie pracy, wyjazdy służbowe, zarabianie na życie, np. handel, załatwianie spraw ).

\section{Podstawowe kategorie zajęć rekreacyjnych respondentów podczas ostatnich wakacji}

A. zajęcia bierne (ruchowo; pozycja odbiorcy) $\mathbf{w}$ domu:

1) odbiór aktualności z mediów (radio, telewizja, prasa, Internet);

2) odbiór innej oferty (np. kulturalnej) z mediów (radio, telewizja, prasa, Internet);

3) odbiór treści z odtwarzaczy (np. magnetofon, video, rzutnik, komputer);

4) czytanie książek i czasopism;

5) inne zajęcia (jakie?

B. zajęcia bierne (j.w.) poza domem:

1) wyjścia na koncerty muzyczne i spektakle teatralne (opera, rewia, festiwal....);

2) wyjścia do kina i na projekcje filmów (np. w klubie);

3) wyjścia do muzeów, galerii (kontakt ze sztuką plastyczną);

4) wyjścia do czytelni (szkolnych, osiedlowych, naukowych, innych);

5) wyjścia na spotkania towarzyskie (do kawiarni, klubów, do znajomych);

6) wyjścia na zawody sportowe (kibicowanie);

7) wyjścia do świątyń i innych miejsc kultu religijnego;

8) zwiedzanie sklepów, realizacja niekoniecznych zakupów;

9) inne zajęcia, np. leżakowanie, plażowanie,

C. zajęcia aktywne (ruchowo, ćwiczenie umiejętności, pozycja nadawcy) w domu:

1) przyjemnościowe wykonywanie zajęć domowych - dbanie o dzieci, rośliny i zwierzęta domowe, „kucharzenie", porządkowanie (np. książek, fotoalbumów,

2) ćwiczenia gimnastyczne (np. joga), aerobic, taniec;

3) gry i zabawy towarzyskie (w tym z dziećmi) np. karty, warcaby, szachy;

4) gra na instrumencie muzycznym, malowanie, rzeźbienie, fotografia kameralna;

5) pisanie wierszy, dzienników, pamiętników, listów;

6) tkanie, haftowanie, szydełkowanie, dzierganie na drutach, szycie i inne robótki ręczne oraz majsterkowanie i modelarstwo);

7) kolekcjonerstwo przedmiotów użytecznych duchowo (pamiątki rodzinne, patriotyczne) i materialnie;

8) inne zajęcia (jakie?

D. zajęcia aktywne (j.w.) poza domem:

1) przyjemnościowa praca w ogródku przydomowym, na działce;

2) zajęcia sportowe bez sprzẹtu: biegi, skoki, gimnastyka, pływanie

a) w terenie (ogródek, działka, park, las, boisko, stadion, zbiorniki wodne: naturalne i sztuczne):

+ spacery, marsze, zbieranie runa leśnego...;

b) pod dachem (sale i hale sport., baseny):...; 
3) zajęcia sportowe ze sprzętem: lekkoatletyka, tenis, rolki, hippika, ...;

a) w terenie: + sanki, narty, rower, paralotnia, kajak, tódź...;

b) pod dachem: + ćwiczenia na siłowni, kręgle...;

4) zespołowy sport amatorski (treningi w stałych grupach): piłka ręczna, siatkówka, koszykówka:

a) w terenie: + piłka nożna, hokej na trawie...;

b) pod dachem: ...;

5) tańczenie (przyjęcia o takim charakterze, dyskoteki, dansingi);

6) amatorskie zajęcia i występy artystyczne: muzyczne, taneczne, teatralne, plastyczne;

7) spotkania w kołach poznawczych, w tym we wspólnotach religijnych;

8) działalność społeczna: duchowo-etyczna, charytatywna, obywatelska, dziennikarska, proekologiczna, krajoznawczo-turystyczna, sportowa;

9) uprawianie form turystyki bez specjalistycznego sprzętu (t. piesza, wycieczki krajoznawcze, .............)

10) uprawianie form turystyki ze środkami transportu lub specjalistycznym sprzętem ( rowerowa, kajakowa, żeglarska,

11) inne zajęcia (jakie? 